\title{
オルトー, パラーnーアルキルフェノール系非イオン界面活性剤の構造と表面張力との関係†
}

（昭 和 35 年 12 月 17 日 受 理）

\author{
石井 義郎・小川知子・水谷，岩夫*
}

前報の各種オクチル基の影響につついて, o- 㧊よび $p$-の $n$-アルキルフェノール（アルキル基 $\mathrm{C}_{4}, \mathrm{C}_{6}, \mathrm{C}_{8}, \mathrm{C}_{10}$ 㧊

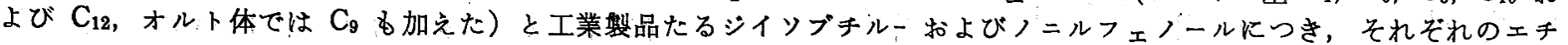
レンオキシド 6, 10 および $15 \mathrm{~mol}$ 付加体を製し, 改良 Wilhelmy 法による $25^{\circ} \mathrm{C}$ の表面張力を求めた。この方法によ り信頼できる静的な表面張力が得られ，Gibbs の吸着式から求めた表面過剩濃度，界面に打ける活性剤分子の吸着断面積、 分子長と構造の関係を考察した。また臨界ミセル濃度と表面過唾濃度との間にむ興味ある関係が認められた。

\section{1 緒言}

アルキルフェノール系非イオン界面活性剤は最近ますますその 用途を拡大しており，石油化学製品たるジイソブチレン, ノネン (プロピレンの 3 量体) からつくったいわゆるオクチルフェノー ル, ノニルフェノールのエチレンオキシド付加体が利用されてい る。しかしながら，前報1であ述べたように，一般的にアルキル 基の炭素原子数, 枝分れ度, 水酸基に対する結合位置などが，こ れらのアルキルフェノールから得られるエチレンオキシド付加体 の界面活性に対してどのような影響を拉よばすかについては全く 不明である。石井ら1) はさきにオルトおよび パラの $n$-オクチル 体, p-ジイソブチル体, 1-エチルヘキシル体, 1,1-メチルエチル アミル体につきエチレンオキシド 5,10 および $15 \mathrm{~mol}$ 付加体 を製し，表面張力，漫透作用，酸食抑制効果汶する影響をしら べた。その際に用いた表面張力の測定法は Traube の滴数計を使 用したが， du Nouy 法ととすに厳密な 静的表面張力の 測定法と しては欠点があるので, 今回は改良 Wilhelmy 法到による垂直板 法を採用した。この方法によると実験結果に示すように $\gamma-\log c$ 曲線もGibbs の吸着式をよく満足する綺麗な直線部分を与える。 それゆえオルト特よびパラの nーアルキルフェノール $\left(\mathrm{C}_{4}, \mathrm{C}_{6}, \mathrm{C}_{8}\right.$, $\left.\mathrm{C}_{10}, \mathrm{C}_{12}\right)$ 扎よび o-nーノニルフェノール，パラー体である市販品 のジイソブチルフェノール怙よびノニルフェノールにつき，それ それれのチレンオキシド 6, 10 拈よび $15 \mathrm{~mol}$ 付加体を製し, この方法により $25^{\circ} \mathrm{C}$ に打ける表面張力を測定し, それらの結果 から構造と表面張力の関係を考察した。

\section{2 実験試料と実験方法}

\section{$2 \cdot 1$ 各種アルキルフェノールの合成}

前報1)にてオルト，パラの nーオクチルフェノールを合成した 場合とほぼ同様な反応条件により，脂肪酸クロリドフフェノー ル，無水塩化アルミニウムをニトロベンゼン中（ときには四塩化 エタンを用いた）で 85〜 $100^{\circ} \mathrm{C}$ に 6〜8 時間反応させ，その後 氷水中に注いで水蒸気蒸留により未反応体と溶媒を留去し，つい でエーテル抽出を行なう。エーテル溶液を $3 \% \mathrm{NaOH}$ で抽出す ると p-オキシアシロフェノンだがアルカリ層に移行して，才

$\dagger$ 本報を「アルキルフェノール系非イオン界面活性剤の構造 と性質の関係（第 2 報)」とする．前報は工化 $61 ， 180$ (1958).

* 名古屋大学工学部工業有機化学教室 : 名古屋市千種区不老 町.

1) 石井, 草野, 文藤, 工化 61,180 (1958).

2) J. L. Ihrig, D. Y.E. Lai, J. Chem. Edn. 34, 196(1957).
ルト体はエーテル溶液中に残るのでオルト，パラ異性体の分離が できる。各オキシアシロフェノンを再結晶または 2 回の減圧蒸留 によって分取したときの実験結果は表 1にまとめて示した。つぎ に Clemesnen 還元によりケト基をメチレン基に変え，相当する nーアルキルフェノールを得る。得られた結果は表 1 に示した。

ここに用いた脂肪酸クロリドは日本油脂 $\mathrm{KK}$ の純脂肪酸 $\mathrm{C}_{6}$, $\mathrm{C}_{10}, \mathrm{C}_{12}$ を反覆精留後クロリドに変えたるので，nーノニル酸は日 本オゾン $\mathrm{KK}$ から，酪酸は化学用純品を使用した。用いたフェ ノールは三井化学工業 KK の工業品を精留したものである。

また $p$-nーブチルフェノールだけは，上記の方法によらず， Ralstọ らの方法に準じて酪酸フェニルの Fries 転位により， ついで Clemensen 還元を行なって得たものである。

表 1 オキシアシロフェノンとアルキルフェノールの收率, 沸点（または融点），ヒドロキシル価

\begin{tabular}{|c|c|c|c|c|c|c|}
\hline \multirow{2}{*}{$\begin{array}{l}\text { アシル基 } \\
\text { またはフ } \\
\text { ルキル基 }\end{array}$} & \multicolumn{2}{|c|}{ オキシアシロフェノン } & \multicolumn{2}{|c|}{ アルキルフェノール } & \multicolumn{2}{|c|}{ ヒドロキシル価 } \\
\hline & 紧率 & 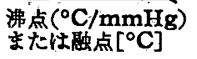 & 荍事 & 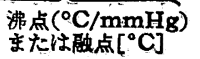 & $\begin{array}{l}\text { 实測 } \\
\text { 値 }\end{array}$ & $\begin{array}{l}\text { 賥算 } \\
\text { 做 }\end{array}$ \\
\hline$o-\mathrm{C}_{4}$ & 51 & $(130-5 / 9)$ & 54 & $(110-5 / 12)$ & 369 & 374 \\
\hline$p-C_{4}$ & 28 & {$[91-2]$} & 45 & $(135-40 / 14)$ & 371 & " \\
\hline$o-\mathrm{C}_{8}$ & 42 & $(184-8 / 11.5)$ & 53 & $(120-5 / 5)$ & 314 & 315 \\
\hline$p-C_{e}$ & 32 & {$[60--1]$} & 73 & $(153-7 / 8.5)$ & 313 & " \\
\hline$o-\mathrm{C}_{\mathrm{\theta}}$ & 44 & $(168-9 / 9)$ & 53 & $(145-50 / 6)$ & 251 & 255 \\
\hline $0-\mathrm{C}_{10}$ & 32 & {$[35-6]$} & 52 & $(174-7 / 9)$ & 236 & 240 \\
\hline$p-C_{10}$ & 36 & {$[52-3.5]$} & 38 & $(185-90 / 8.5)$ & 237 & \\
\hline$o-\mathrm{C}_{12}$ & 45 & $(225-30 / 3)$ & 57 & $(210-5 / 6)$ & 209 & 214 \\
\hline$p-C_{12}$ & 27 & {$[70-1]$} & 62 & {$[64-5]$} & 214 & " \\
\hline
\end{tabular}

ここに合成したオキシアシロフェノンおよびアルキルフェノー ルは前報1) と同様, 赤外吸収スペクトルにより.他の異性体の混在 しないことを確認して用いた。

\section{$2 \cdot 2$ エチレンオキシド付加体の調製}

前報1) と同様，それぞれのアルキルフェノールに $1 \mathrm{~mol} \%$ の カセイソーダを触媒として加え $160^{\circ} \mathrm{C}$ にて $80 \sim 100 \mathrm{~cm}^{3} / \mathrm{min}$ の 流速にてエチンンオキシドを通じ，その重量増加から，なるべく $6,10,15 \mathrm{~mol}$ 付加体に近いるのを調製した。各場合に得られた 平均付加モル数は後述の表 2,3 中に示してある。またオルト, パラの $n$-オクチルフェノール枕よび ジイソブチルフェノールに ついては前報1)に用いたエチンンオキシド付加体をそのまま使用 した。したがってこの 3 者は $5,10,15 \mathrm{~mol}$ 付加体である。， ニルフェノール（トリプロピレンとフェノールの縮合体）は Jefferson 社のものをそのまま使用しエチレンオキシド付加体を得 た。

\section{$2 \cdot 3$ 表面張力の測定}

3) A.W.Ralstion, M.R. McCorkle, et al, J. Org. Chem. 5, 645 (1940). 
緒言にも述べたように前 報》に用いた Traube の滴 数計あるいは du Nouy 法 よりも信頼性の大きな静的 な表面張力を与皇測定方 法として改良 Wilhelmy 法2)による垂直板法を採用 した。用いた装置の略図は 因 1 に示した。 $25 \pm 0.2^{\circ} \mathrm{C}$ の定温槽に既知濃度の活性 剤溶液を入れたビーカーを 置き，浴と同温になった 後, 図に示すよ5に天科の 一方のアームから針金で吊 したスライドガラスを液に

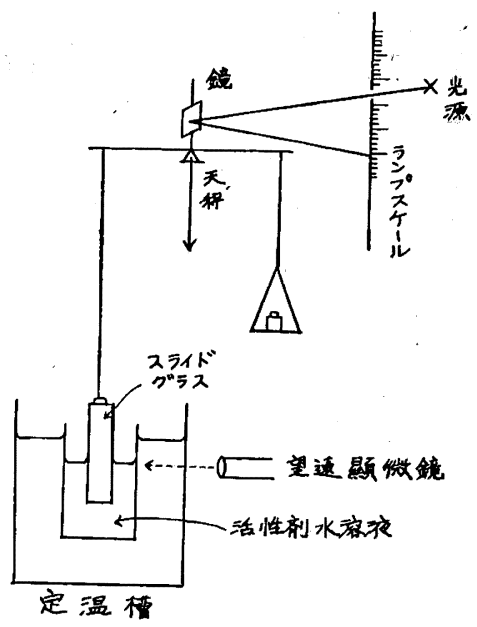

図 1 表面張力測定装置
つけ，天科の分銅と，ランプスケールから，静止状態を保ったと きの分銅の重さ $T$ と, 溶液につかったスライドガラスの長さ $h$ を求め，次式から表面張力 $\gamma$ を知る。

$$
T+\rho S_{\mathbf{g}} h=W_{\mathbf{g}}+L \gamma
$$

ここで $W_{\mathrm{g}}$ は空気中での針金拈よびスライドガラスの重量, $L$ はガラス板の周囲の長さ, $S$ はガラス板の断面積である。純水に ついての予備実験から $L, S$ はそのスライドガラスについて一定 値として得られる。るちろんスライドガラスは断面積, 周囲の長 さが各部分において均一なものを用い，その清浄性については特 に留意する必要がある。この方法によって静的な表面張力が測定 できるが, アルキル鎖長が $\mathrm{C}_{10} ， \mathrm{C}_{12}$ のよ5に長鎖の場合, エチ レンオキシド付加体の希薄溶液に特いては，静止状態に到達する のに 3〜5 時間を要し, 濃厚溶液ほど，またアルキル鎖長が短か いほど短時間で静止状態が得られる。

\section{3 実 験 結 果}

前節で得られた各種アルキルフェノールのエチレンオキシド付 加体について, その濃度を変えて水溶液の表面張力を前節で述へ た方法により測定した。そ。結果を, 表面張力 $r(\mathrm{dyne} / \mathrm{cm})$ 対 $\log c(\mu \mathrm{mol} / l)$ Kプロットしたのが図 2〜7 である。オルト，パ ラ系別にそれぞれ 6, 10 および $15 \mathrm{~mol}$ 付加体についてまとめ て図示した。図中の数字はアルキル鎖の炭素数を示しており，4' はジイソブチル体，6' $6^{\prime}$ は市販のノニル (トリイソプロピル) 体を

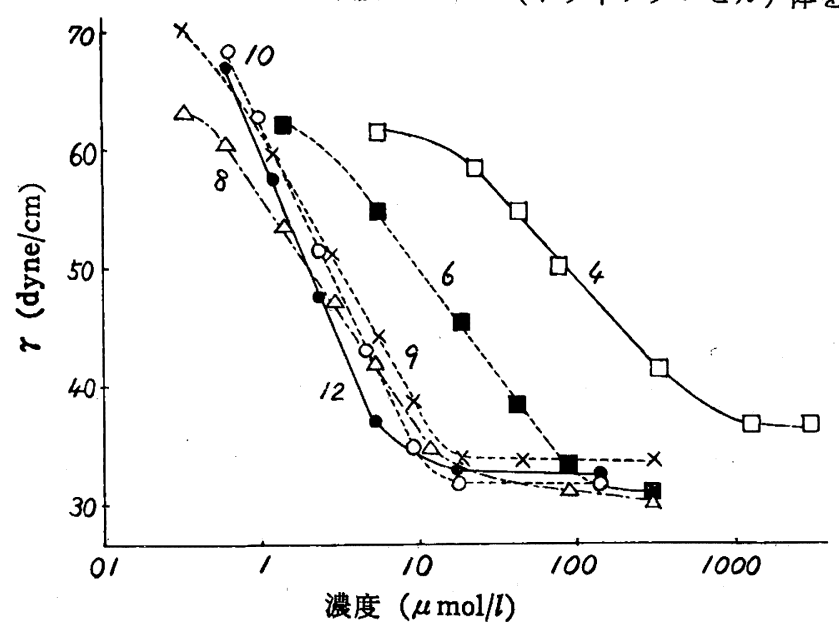

図 2 オルト系-6 EO
指している。ここで測定試料の純度その他について触れておく。 前節の方法で得られたエチンンオキシド付加体は, 目的の化合物 以外飞触媒として働いたナトリウムアルキルフェノキシドおよび 副反応生成物であるポリエチレングリコールが混在している。こ の両者を除去するため宮川, 長瀬の記載)飞準じて処理を行ない, $p-n-\mathrm{C}_{8}-10 \mathrm{EO}$ 付加体と $0-n-\mathrm{C}_{12}-6 \mathrm{EO}$ 付加体について未処理品 と精製品について表面張力を測定したところ精製処理によって表 面張力濃度曲線は，ほとんど変化しないことを認めた。したがっ て, 本実験に扣いては特別の精製処理を施すことなく表面張力の 測定に用いた。つぎに注意しておくことはエチレンオキシド付加

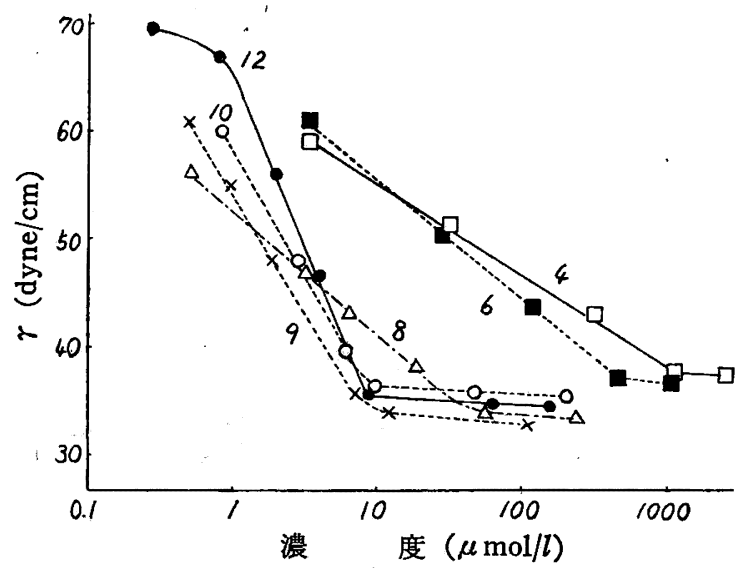

図 3 オルト系-10 EO

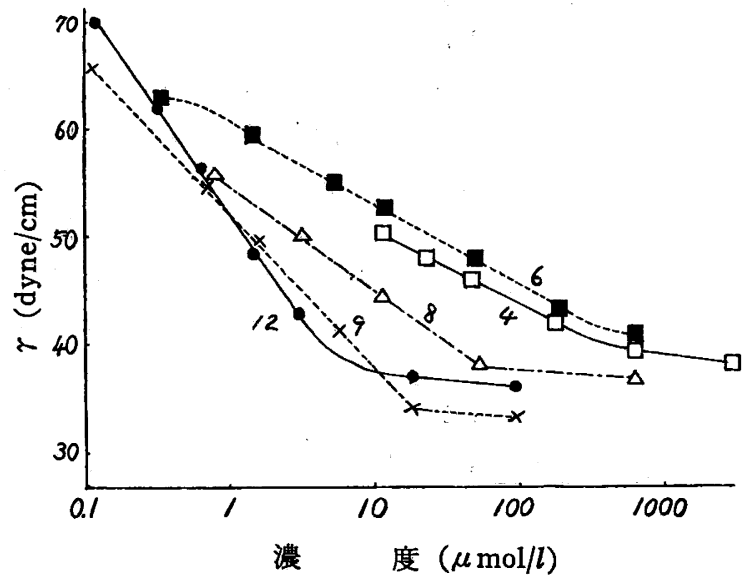

図 4 オルト系-15 EO

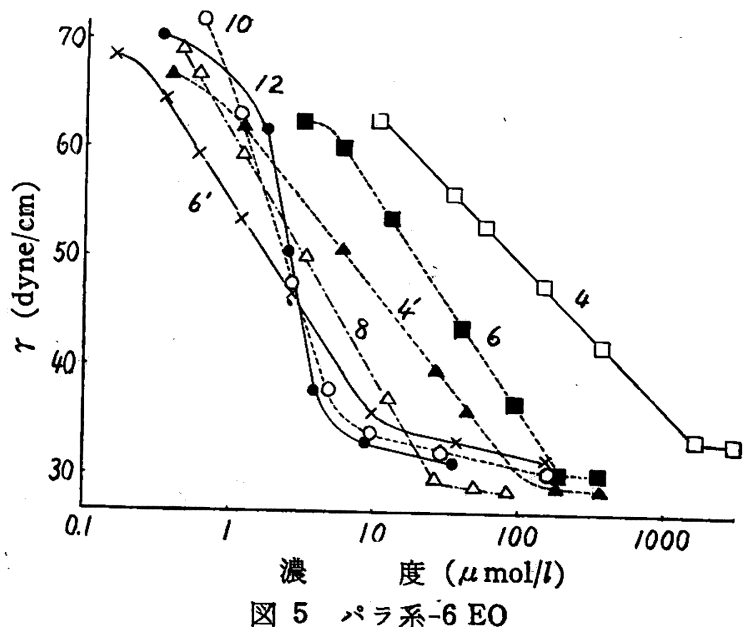

4）宮川，長瀬，“高分子実験学講座第 10 巻”, p. 171 (昭 33）共立出版. 


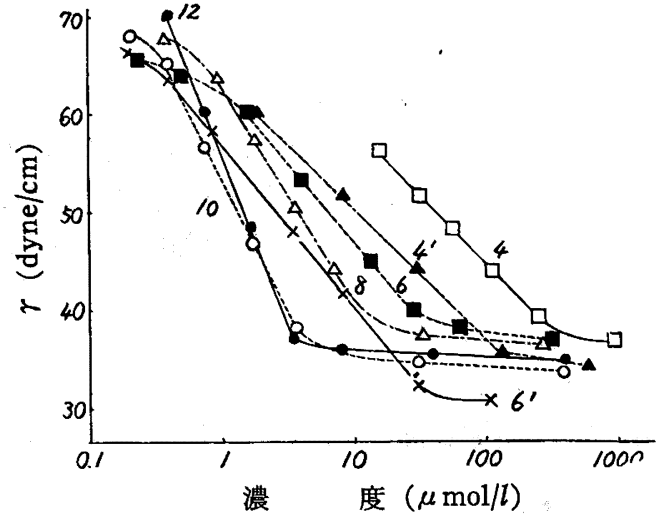

図 6 パラ系-10 EO

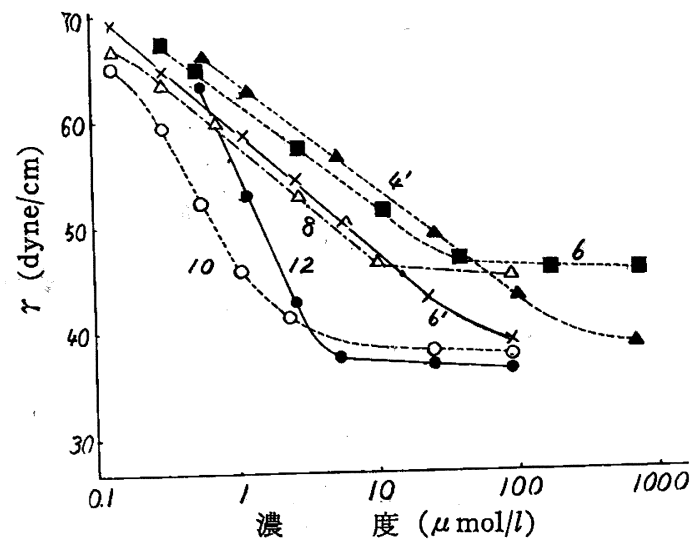

因 7 パラ系 $-15 \mathrm{EO}$

体が各モル付加体の混合物であって，6 $\mathrm{mol}$ 付加体といっても平 均的に $6 \mathrm{~mol}$ 付加したるのであることである。しかし著者らの 別の研究 (未発表) により,アルキルフェノールとそのエチレン オキシド付加体は，それそれれそのアルキル鎖長には影響を受けな い酸性度を有していること，およびそれぞれのエチレンオキシド 付加速度間にる大差は認められないので Weibull, Nycander ${ }^{5)}$ の示した分布定数 cはほとんどちがわないことがわかっている。 それゆえオルト，パラ体とすアルキル鎖が異なってもそのモル分 布はほぼ等しいと考えることができる。従って $160^{\circ} \mathrm{C} に て 一$ 定速 度でエチンンオキシドを付加させて得た各付加体は混合物である とはいえ，それぞれの付加モル数に打いてモル分布のほ医等しい 混合物であるから, 相互の比較には十分有意義な化合物であると いうことができよう。

図 2〜7 を見るとオルト， パラ体とす $\mathrm{C}_{4}, \mathrm{C}_{6}$ 体は $\mathrm{C}_{8} \sim \mathrm{C}_{12}$ 体 にくらべ高濃度で $r$ が大きくなっいること，したがってC. M.C. が大であることがわかる。また各図とも $r-\log c$ 曲線には Gibbs の吸着式をよく満足する直線部分が明瞭に得られて括り, 後述の考察のようにこれから信頼すべき表面過剩濃度を求めるこ とができる。

アルキル鎖長が長くなると直線部分の勾配は急になってくるこ とが明らかである。

\section{4 考察}

前節で得た結果から各化合物とも $r$ 対 $\log c$ 曲線に良好な直 線勾配部分が得られるので，(2) 式の Gibbs 吸着式から表面過

5) B. Weibull, B. Nycander, Acta Chem. Scand. 8, 847 (1954).
輁濃度 $\Gamma\left(\mu \mathrm{mol} / \mathrm{cm}^{2}\right)$ が得られ，（3）式から界面に拈ける吸 着剂分子 1 個为たりの占有面積 $a\left(\AA^{2}\right)$ と長さ $l(\AA)$ を求める ことができる。ただし密度 $d$ は低濃度に怙いては大差がないの で 1 と仮定した（ $M$ は分子量， $N$ はアボガドロ定数）。

$$
\begin{array}{ll}
\Gamma=-\frac{1}{2.303 R T} \frac{d \gamma}{d \log c} \\
a=\frac{1}{N \Gamma} \quad l=\frac{\Gamma M}{d}
\end{array}
$$

また図 2〜7 から，それぞれの付加体について臨界ミセル濃度 C. M.C. $(\mu \mathrm{mol} / l)$ が得られるから，これも含めて表 2 ，表 3 K 示した。

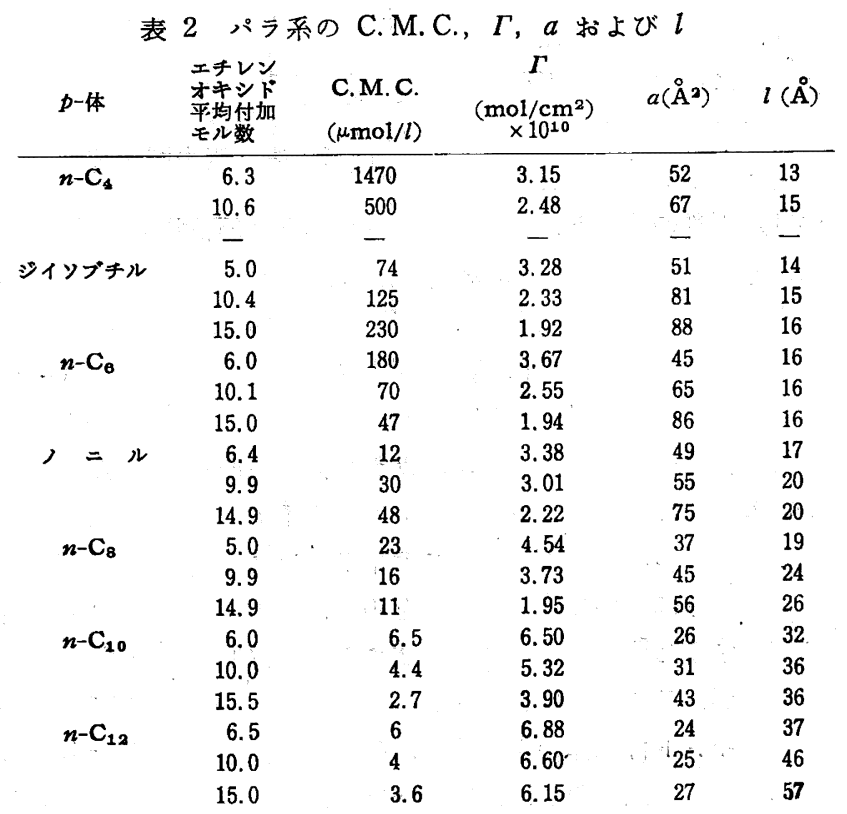

\begin{tabular}{|c|c|c|c|c|c|}
\hline o-体 & 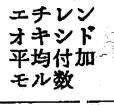 & $\begin{array}{l}\text { C. M.C. } \\
(\mu \mathrm{mol} / l)\end{array}$ & $\begin{array}{c}\Gamma \\
\left(\mathrm{mol} / \mathrm{cm}^{2}\right) \\
\times 10^{10}\end{array}$ & $a\left(\AA^{2}\right)$ & $l(\AA)$ \\
\hline \multirow{3}{*}{$n-\mathrm{C}_{4}$} & 7.1 & 800 & 2.72 & 61 & 13 \\
\hline & 10.1 & 1100 & 1.53 & 108. & 9 \\
\hline & 15.5 & - & 1.21 & 137 & 10 \\
\hline \multirow{3}{*}{$n-C_{e}$} & 6.0 & 100 & 3. 28 & 51 & 14 \\
\hline & 10.2 & 500 & 1.99 & 84 & 12 \\
\hline & 15.1 & 740 & 1,29 & 128 & 11 \\
\hline \multirow[t]{3}{*}{$n-\mathrm{C}_{8}$} & 5.5 & 122 & 3.67 & 45 & 17 \\
\hline & 10.0 & 30 & 2.69 & 62 & 17 \\
\hline & 14.5 & 45 & 2.07 & 80 & 18 \\
\hline \multirow[t]{3}{*}{$n-C_{\vartheta}$} & 6.5 & 19 & 4.94 & 34 & 24 \\
\hline & 10.6 & 8 & 3.69 & 45 & 25 \\
\hline & 15.0 & 22 & 2.68 & 62 & 24 \\
\hline \multirow[t]{3}{*}{$n-\mathrm{C}_{10}$} & 6.1 & 12 & 5.22 & 31 & 26 \\
\hline & 10.1 & 8 & 3. 99 & 42 & 27 \\
\hline & 15.0 & - & - & - & - \\
\hline \multirow[t]{3}{*}{$n-\mathrm{C}_{12}$} & 6.0 & 9 & 5.79 & 29 & 30 \\
\hline & 10.1 & 7 & 4. 32 & 38 & 31 \\
\hline & 15.0 . & 5 & 3.39 & 43 & 35 \\
\hline
\end{tabular}

表 3 オルト系の C. M. C., $\Gamma, a$ おび $l$

さらに表 2, 3 から, アルキルフェノールの側鎖アルキル鎖長 の炭素数と吸着断面積 $a$ の関係をプロットしたすのが図8であ って，パラ系にて枝分れ側鎖をるつ化合物はそれぞれ主鎖に相当 する炭素数のところに，それぞれの記号を付して記してある。

また表面過剩濃度 $\Gamma$ と C.M.C. の関係をプロットした図が 図 9 である（数字はエチレンオキシド付加モル数，横軸は対数目 盛)。これらの図および表から次の結諭が得られる。

（1）アルキルフェノールのエチレンオキシド付加体は，オル 


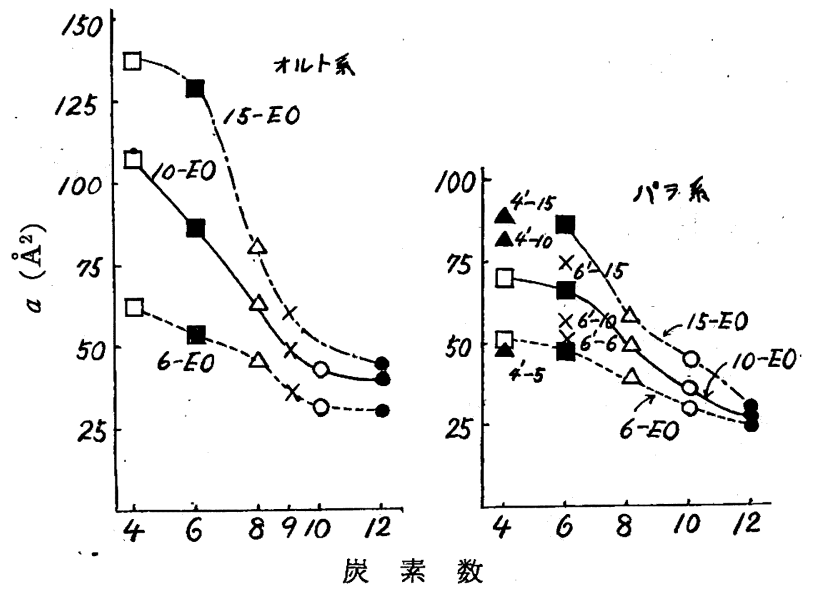

因 8 側鎖炭歯数々吸着断面積の関係

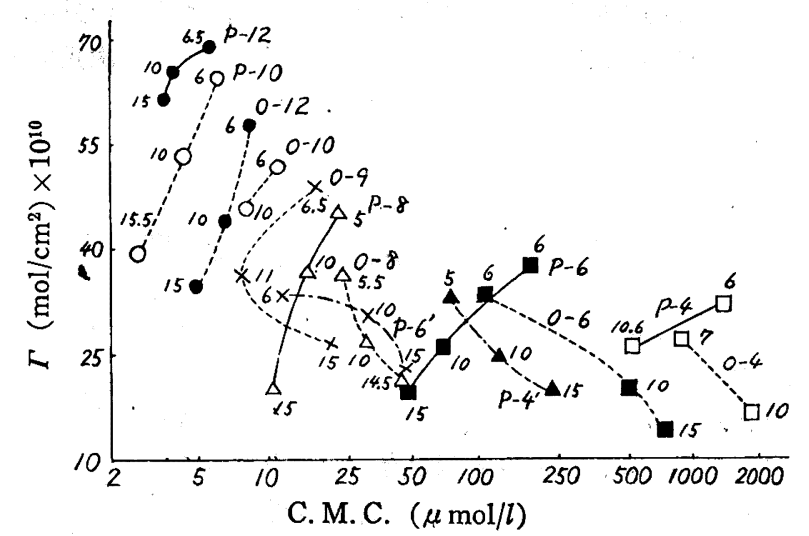

因 9 表面過剰と C.M.C. の関係

ト，パラ両系ともエチレンオキシド付加モル数が $6 \rightarrow 10 \rightarrow 15 \mathrm{~mol}$ と増加すると, 表面過剩濃度が減少し, したがって吸着断面積 $a$ が増加する。

（2）エチレンオキシド付加モル数の増加による吸着断面積 $a$ 値の増加は, アルキル鎖長の長いほど小さく, パラ系ではオルト 系にくらべてその差はずっと小さい。

（3）枝分れ側鎖を有する化合物は，分枝鎖の主鎖をなす炭素 数を有するノルマル体にほぼ相応した表面過剩または断面積を持 つ。

（4） パラ系ではアルキル鎖が $\mathrm{C}_{8}$ 以下の場合，エチレンオキ シドの付加数の増加に伴ない, 断面積 $a$ 值は増大するが, 長さ $l$ はほぼ一定であって， C 8 以上になるとしだいに $a$ 值は変わら ず $l$ 值だけが增加する傾向を生ずる。これはアルキル鎖が長くな るとアルキル鎖間の van der Waals カが増大して, 界面に扣け る活性剤分子の緊密充填となり， $a$ 值はベンゼン環の断面積 25 $\AA^{2}$ に接近し，エチレンオキシドの付加モル数が增加しても $a$ 值 には影響を与えず，分子の長さが増大するたけであるからだろう。 アルキル鎖が短かい場合はこの逆であって，分子の長さ $l$ は土チ レンオキシド付加モル数がふえてもほぼ一定で， $a$ 值だけが増大 する傾向を示するのと考えられる。

（5）図 9 の表面過剰と C.M.C. の関係から興味ある結果が 得られる。すなわち $p$ ーノルマル体ではエチレンオキシド付加モ ル数 $6 \rightarrow 15$ の增大は $\Gamma$ むC.M.C. もともに低下させる。一方 o-ノルマル体では $\mathrm{C}_{4} \sim \mathrm{C}_{8}$ に括いては $\Gamma$ は低下するが, C. M. C. は増大し， $\mathrm{C}_{10}, \mathrm{C}_{12}$ に嗦いてはパラ系と同じ傾向を示し， $\mathrm{C}_{9}$ 体
では C.M.C.は 6 $\rightarrow 11 \mathrm{~mol}$ では减少し，15 mol になるとまた 増大している。またパラ系にてもジイソブチル，ノニル体のよう に枝分れを有するものはオルト系に類似の挙動を示している。こ のことは 0 ーアルキル基は $p$-アルキル基にくらべて活性剤分子の 親水性を大きくし，また枝分れ基子オルト系に類似の親水性を分 子に与えるるのと考えられる。この点, 非イオン活性剤の HLB を論ずるとき注意すべき事柄であろう。

ノニルフェノールに関しては Hsiao ら)が de Nouy 法 $\left(25^{\circ} \mathrm{C}\right)$ により，エチレンオキシド付加モル数を変えて C.M.C., $\Gamma, a$ などを求めている（たたし使用試料は General Aniline 社の製

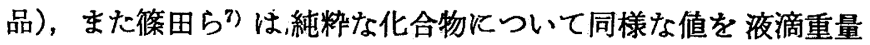
法 $\left(25^{\circ} \mathrm{C}\right)$ で求めているので，この両者の結果を表 4 に示した。 Hsiao らの $\Gamma$ と C.M.C. の値を著者の結果とくらべると $\Gamma$ 値 は大差ないが, C.M.C. は Hsiao の值の方が大きい。Hsiao ら は C.M.C. とエチレンオキシド付加モル数 $n$ との間に次の関係 式を提出しているが，一般的に妥当する式でないことは，われわ れの結果から見て明らかである。 $\ln ($ C. M.C. $)=0.056 n+3.87$ 。

\begin{tabular}{|c|c|c|c|c|}
\hline 料 & $\underset{\text { Eル数 }}{\mathrm{E}}$ & $\underset{(\mu \mathrm{mol} / \mathrm{l})}{\mathbf{C} \cdot \mathbf{M} \cdot \mathbf{C}}$ & $\underset{\substack{\left(\mathrm{mol} / \mathrm{cm}^{2}\right) \\
\times 10^{10}}}{\Gamma}$ & $a\left(\AA^{2}\right)$ \\
\hline ジイソブチルフェノール & 8.5 & $180 \sim 230$ & 3.15 & 53 \\
\hline \multirow[t]{6}{*}{ ノニルフェノール } & 9.5 & $78 \sim 90$ & 3.05 & 55 \\
\hline & 10.5 & $75 \sim 90$ & 2.75 & 60 \\
\hline & 15 & $110 \sim 130$ & 2.30 & 72 \\
\hline & 20 & $135 \sim 175$ & 2.00 & 82 \\
\hline & 30 & $250 \sim 300$ & 1.65 & 101 \\
\hline & 100 & 1,000 & 0.95 & 173 \\
\hline$n-\mathrm{C}_{8} \mathrm{H}_{17} \mathrm{OH}$ & - & - & 5.6 & 30 \\
\hline$n-\mathrm{C}_{8} \mathrm{H}_{17} \mathrm{OCH}_{2} \mathrm{CH}_{2} \mathrm{OH}$ & - & 4,900 & 5.2 & 32 \\
\hline$n-\mathrm{C}_{8} \mathrm{H}_{17} \mathrm{OCH}_{2} \cdot \mathrm{CHOH} \cdot \mathrm{CH}_{2} \mathrm{OH}$ & - & 5,800 & 5.2 & 32 \\
\hline$n-\mathrm{C}_{8} \mathrm{H}_{17} \mathrm{OCH}(\mathrm{CHOH})_{5}$ & - & 25,000 & 4.0 & 41 \\
\hline$n-\mathrm{C}_{12} \mathrm{H}_{25} \mathrm{O}\left(\mathrm{CH}_{2} \mathrm{CH}_{2} \mathrm{O}\right)_{5 \cdot 8} \mathrm{H}$ & - & 250 & 4.9 & 34 \\
\hline
\end{tabular}

さらに図 9 から，pーノルマルアルキル体ではエチレンオキシド 付加モル数 6，10，15 の線をそれぞれつらねると，図中左上部 すなわち低 C.M.C., 高 $\Gamma$ (ただし $\Gamma$ はこれ以上は增大しにく い）のところに収斂する傾向を示す。このことはアルキルフェノ ール系非イオン活性凧の一つの限界を指示するすのである。 $p-n-$

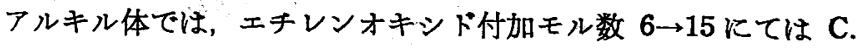
M.C. が減少する一方であるが，さらに，エチレンオキシド付加 モル数を増加するとオルトーC 9 体に見られるよう飞，やがて，

C.M.C. が增大する方向に変曲点を生じよう。

以上の結果から，アルキルフェノール系非イオン活性剤につい て，表面張力と構造の関係が明らかになり，現在工業的に使用さ れているジイソブチルー, ノニルフェノール系以外にも，な拉有 用な物質が存在すべきことが予想される。

(昭和 35 年 10 月 15 日, 第 13 回コロイド化学討論会（横 浜）講演）

本研究に際し有益な討諭をいただいた㮩の水女子大学立花太 郎教授に感謝する。また本文に記した試料をいたたいた各社に感 謝する。本研究は文部省科学試験研究費に負らところが大きいこ とを付記する。

6) L. Hsiao, H.N. Dunning J. Phys. Chem. 60, 657(1956).

7）篠田, 山中, 木下, J. Phys. Chem. 63, 648 (1959). 